\title{
Kualitas Fisik Daging Ayam Broiler yang Dipelihara di Kandang Closed House pada Ketinggian Dataran Berbeda
}

\author{
Physical Quality of Broiler Meat Kept in Closed House at Different Altitudes
}

\author{
B. Prasetyo ${ }^{1}$, L. D. Mahfudz ${ }^{2}$, dan M. H. Nasoetion ${ }^{3}$ \\ Fakultas Peternakan dan Pertanian Universitas Diponegoro \\ Jl. Prof. Soedarto No.13, Tembalang, Kec. Tembalang, Kota Semarang, Jawa Tengah 50275 \\ Correspondinge-mail :1mahfudz@gmail.com
}

\begin{abstract}
This study was aimed to examine the effect of different altitude levels on the physical quality of broiler's meat that is rearing closed house. The experiment was carried out at close house which at three different plains with a maintenance period of 28 days. The design used completely randomized design (CRD) with 3 treatments and 8 replications, each plains consisted of 2 close houses. Data were analyzed by analysis of variance (ANOVA) at the $5 \%$ level with $\mathrm{F}$ test to known the effect of treatment and if there are significantly effect of treatment then contnued to Duncan's test. The treatments were T1 (lowland, $<400 \mathrm{~m}$ ), T2 (moderate land, $400-700 \mathrm{~m}$ ) and T3 (highland,>700 m). The parameters measured were water holding capacity (WHC), pH, cooking losses, drip loss and color. The results showed that broilers kept in closed house at the highland (Ampel) had cooking losses, drip loss and brightness of the breast meat color significantly $(\mathrm{P}<0.05)$ better than the lowland (Demak). The $\mathrm{pH}$ value of meat was close to normal at moderate altitude (Gunungpati). The altitude had no significant $(\mathrm{P}>0.05)$ effect on the level of redness and yellowish of the broiler chicken thigh meat. The conclusion of this study was that broiler chickens kept in closed house at the highlands had the best physical quality of meat.
\end{abstract}

Key words: broiler chicken, closed house, altitude, physical quality of meat

\begin{abstract}
ABSTRAK
Penelitian ini bertujuan untuk mengkaji pengaruh perbedaan ketinggian dataran terhadap kualitas fisik daging ayam broiler yang dipelihara pada kandang closed house. Percobaan dilakukan dengan menggunakan kandang closed house dengan ketinggian dataran berbeda dengan lama pemeiharaan 28 hari. Rancangan yang digunakan rancangan acak lengkap (RAL) dengan 3 perlakuan dan 8 ulangan. Setiap unit percobaan terdiri dari 2 kandang closed house. Data dianalisis ragam dengan uji $\mathrm{F}$ pada taraf $5 \%$ untuk mengetahui pengaruh perlakuan. Apabila terdapat pengaruh perlakuan yang nyata dilanjutkan dengan uji Duncan. Perlakuan yang diberikan yaitu: T1 (dataran rendah, <400 mdpl), T2 (dataran sedang, $400-700 \mathrm{mdpl}$ ) dan T3 (dataran tinggi, >700 mdpl). Parameter yang diukur yaitu water holding capacity (WHC), $\mathrm{pH}$, susut masak, drip loss dan warna. Hasil penelitian menunjukan bahwa ayam broiler yang dipelihara dalam kandang closed house di dataran tinggi (Ampel) memiliki susut masak, drip loss dan kecerahan warna daging dada nyata $(\mathrm{P} \leq 0,05)$ lebih baik dibandingkan pada dataran rendah (Demak). Nilai pH daging yang mendekati normal pada ketinggian dataran sedang (Gunungpati). Ketinggian dataran tidak berpengaruh nyata $(\mathrm{P}>0,05)$ terhadap tingkat kemerahan dan kekuningan daging paha ayam broiler. Simpulannya adalah ayam broiler yang dipelihara dalam kandang closed house di dataran tinggi memiliki kualitas fisik daging yang paling baik.
\end{abstract}

Kata kunci : ayam broiler, closed house, ketinggian dataran, kualitas fisik daging

\section{PENDAHULUAN}

Ayam broiler merupakan ayam yang telah mengalami perbaikan genetik sehingga memiliki produktivitas yang tinggi dalam produksi daging. Ayam broiler memiliki kelebihan yaitu memiliki pertumbuhan cepat, FCR rendah, kaki besar dan memiliki banyak timbunan daging. Ayam broiler memiliki kelemahan yaitu mudah stress, tidak tahan panas dan imunitasnya rendah sehingga mempengaruhi fisiologis ternak dan rentan terhadap penyakit dan mempengaruhi tingkat deplesi ternak.

Indonesia merupakan negara tropis yang memiliki suhu dan kelembaban yang tinggi. Untuk meminimalisir suhu dan kelembaban dalam memelihara ayam broiler, dengan modifikasi kandang dengan kandang tertutup (closed house) yang dilengkapi dengan pengatur suhu dan sirkulasi udara. Indonesia memiliki kondisi 
topografi yang beragam dengan ketinggian dataran yang berbeda-beda. Ketinggian dataran tersebut dikategorikan menjadi 3 yaitu dataran tinggi ( $>700 \mathrm{~m} \mathrm{dpl)}$, dataran sedang $(400-700 \mathrm{~m}$ dpl) dan dataran rendah $(<400 \mathrm{~m} \mathrm{dpl})$ (Istiawan dan Kastono, 2019).

Perbedaan ketinggian dataran berpengaruh pada makroklimat (suhu, kelembaban, kecepatan angin dan radiasi matahari dengan kata lain memiliki mikroklimat yang berbeda. Semakin tinggi dataran memiliki suhu makroklimat yang rendah sehingga mempengaruhi tingkat konsumsi ternak yang berdampak pada kualitas daging yang lebih baik yang berkaitan dengan tingkat perforna ternak. Semakin rendah dataran memiliki suhu makroklimat yang tinggi sehingga mempengaruhi tingkat stres pada ternak yang berkaitan dengan fisiologis dan tingkat deplesi ternak. Perbedaan ketinggian dataran berpengaruh pada makroklimaat (suhu, kelembapan, kecepatan angin dan radiasi matahari). Perbedaan makroklimat tiap ketinggian dataran ini mempengaruhi mikroklimat pada kandang closed house. Mikroklimat yang tidak normal atau ekstrim dapat menyebabkan efek negatif pada pertumbuhan dan perkembangan serta kualitas produk ternak. Mikroklimat yang ekstrim juga dapat mempengaruhi kondisi fisiologis ternak (Sohail et al., 2010) dan dapat berpengaruh terhadap kualitas fisik daging ayam $(\mathrm{pH}$, susut masak, daya ikat air, drip loss dan warna).

Kualitas fisik daging ( $\mathrm{pH}$, susut masak, drip loss dan warna) pada ayam yang dipelihara di dataran tinggi memiliki kualitas fisik daging lebih baik dibandingkan dengan ayam yang dipelihara di dataran rendah dan sedang, tapi daya ikat air daging ayam broiler yang dipelihara di dataran rendah lebih baik dibandingkan dengan ayam yang dipelihara di dataran tinggi dan dataran sedang (Astuti et al., 2012). Dataran rendah memiliki suhu yang lebih tinggi dibandingkan dengan dataran sedang maupun dataran tinggi. Zhang et al. (2012) melaporkan bahwa dengan memanipulasi suhu dalam kandang yang dibagi menjadi 3 kategori suhu, yaitu : suhu normal $23^{\circ} \mathrm{C}$. Suhu konstan $34^{\circ} \mathrm{C}$ tinggi dan suhu antara 23$36^{\circ} \mathrm{C}$, menunjukkan bahwa ayam broiler yang dipelihara di kondisi suhu yang tinggi dapat menyebabkan stres berdasarkan pengamatan dari bobot badan, kualitas fisik daging, konsumsi pakan dan mortalitas dibandingkan dengan ayam yang dipelihara di suhu yang normal.

Tujuan dari penelitian ini adalah untuk mengkaji pengaruh perbedaan ketinggian dataran terhadap kualitas fisik daging ayam broiler yang dipelihara pada kandang closed house. Manfaat dari penelitian ini adalah memperoleh informasi mengenai manajemen pemeliharaan ayam broiler dalam kandang closed house dan mengetahui perbedaan kualitas fisik daging ayam broiler yang dipelihara pada kandang closed house dengan ketinggian dataran yang berbeda. Hipotesis penelitian ini adalah perbedaan ketinggian dataran menyebabkan makroklimat dan mikroklimat kandang berbeda yang mempengaruhi kualitas fisik daging ayam broiler yang dipelihara di kandang closed house.

\section{MATERI DAN METODE}

\section{Materi Penelitian}

Materi yang digunakan pada penelitian ini yaitu ayam broiler dan kandang closed house di 3 dataran mitra dari Charoen Pokphand. Setiap dataran dipilih dua kandang. Peralatan yang digunakan yaitu centrifuge, aquades, keranjang ayam, pisau, $\mathrm{pH}$ meter, waterbath, tisu, alat tulis, timbangan analitik dan tali benang.

Penelitian pengaruh ketinggian dataran terhadap kualitas fisik daging ayam broiler (daya ikat air, $\mathrm{pH}$, susut masak, drip loss dan warna) dengan menggunakan Rancangan Acak Lengkap (RAL) 3 perlakuan dan 8 ulangan. Perlakuan yang digunakan yaitu satu faktor, yaitu ketinggian tempat yang meliputi: T1 dengan ketinggian $<400$ mdpl (kandang closed house di daerah Demak), T2 dengan ketinggian 400 - 700 mdpl (kandang closed house di daerah Gunungpati) dan T3 dengan ketinggian $>700$ mdpl (kandang closed house di daerah Ampel).

Metode pengambilan sampel yaitu dengan mengambil ayam pada saat panen (28 hari) dengan jumlah 2 ekor ayam tiap pen, sehingga satu kandang diambil 8 ekor, setiap dataran ada 16 ekor, seluruh sampel menjadi 48 ekor. Selanjutnya sampel ini dilakukan pemuasaan dan dibawa ke Rumah Pemotongan Unggas (RPU) terdekat untuk carcassing dengan pengambilan daging bagian dada dan paha. Sampel ini kemudian dibawa ke laboratorium Produksi Ternak Unggas Universitas Diponegoro untuk dilakukan analisis kualitas fisik daging ayam $(\mathrm{pH}$, Water Holding Capacity (WHC), drip loss, susut masak dan warna).

\section{Mengukur pH Menurut Metode Legowo et al. (2005)}

Sebelum dilakukan pengukuran elektroda dibilas dengan akuades dan $\mathrm{pH}$ meter dikalibrasi 
dengan larutan buffer $\mathrm{pH} 7$ dan 4 . Sampel ditimbang $0,5 \mathrm{gr}$ bagian dada dan $0,5 \mathrm{gr}$ bagian paha, selanjutnya dihomogenkan dengan cara menumbuk dengan mortar sampai halus dan ditimbang kembali. Setelah itu disiapkan $50 \mathrm{ml}$ aquades dan sampel dimasukkan ke dalam aquades dan aduk merata. Tahap terakhir $\mathrm{pH}$ meter dimasukkan ke dalam larutan sampel dan dilihat angka dalam $\mathrm{pH}$ meter.

\section{Mengukur Water Holding Capacity Menurut Metode Barbut (1993)}

Caranya sebagai berikut timbang tube, $0.5 \mathrm{gr}$ bagian dada dan $0.5 \mathrm{gr}$ bagian paha, lalu daging dihomogenkan dengan cara menumbuk dengan mortar sampai halus. Sampel kemudian dimasukkan ke dalam tube dan ditambahkan $\mathrm{NaCl}$ sebanyak $1 \mathrm{ml}$. Selanjutnya sampel disentrifugasi selama 3 menit dengan kecepatan $8000 \mathrm{rpm}$. Setelah itu supernatan dibuang dan endapan ditimbang. Tahap terakhir masukan rumus Rini et al. (2019) yaitu :

$\mathrm{WHC}=\frac{1 \mathrm{ml} \text {-supernatan yang dibuang }(\mathrm{ml})}{1 \mathrm{ml}} \times 100 \%$

\section{Mengukur Drip Loss Menurut Metode} Wanniatie (2012)

Caranya sebagai berikut timbang 4gr bagian dada dan 4gr bagian paha dan homogenkan. Lalu masukan dalam plastik zip lock dan jangan sampai ada udara di didalam plastik. Selanjutnya masukan kedalam kulkas dengan suhu $4^{\circ} \mathrm{C}$ selama $24 \mathrm{jam}$. Tahap terakhir timbang sampel dan hitung menggunakan rumus berdasarkan Rini et al. (2019) yaitu :

$$
\text { Drip loss }=\frac{\mathrm{x}-\mathrm{y}}{\mathrm{x}} \times 100 \%
$$

\section{Mengukur susut masak menurut metode Soeparno (1992)}

Sampel bagian dada ditimbang 4 gr dan 4 gr bagian paha dan masukan dalam plastik zip lock dan jangan sampai ada udara di dalam plastik. Sampel direbus dengan menggunakan water bath selama 2 jam dengan suhu $80^{\circ} \mathrm{C}$. Lalu dinginkan sampel dengan menggunakan air mengalir selama 15 menit dan timbang sampel dan hitung menggunakan rumus Rini et al. (2019) yaitu :

Susut masak $=\frac{x-y}{x} \times 100 \%$

\section{Mengukur warna daging ayam}

Nilai warna diukur dengan cara menggunakan alat chromatometer minolta colour reader yang terdiri dari: $L^{*}$ (Kecerahan), a* (kemerahan) dan $b^{*}$ (kekuningan) pada permukaan posterior daging dada dan paha dan warna diukur pada tiga sisi berbeda.

\section{HASIL DAN PEMBAHASAN}

\section{pH Daging Ayam Broiler}

Hasil analisis ragam menunjukan bahwa ketinggian dataran berpengaruh sangat nyata $(\mathrm{P}<0,01)$ terhadap $\mathrm{pH}$ daging ayam broiler. Ratarata nilai $\mathrm{pH}$ daging ayam broiler berkisar 5,24 6,72 (Tabel 1.)

Tabel 1. Hasil perbedaan ketinggian dataran terhadap $\mathrm{pH}$ daging ayam broiler.

\begin{tabular}{cccc}
\hline Ulangan & T1 & T2 & T3 \\
\hline U1 & 6,68 & 5,53 & 6,78 \\
U2 & 6,43 & 5,38 & 6,65 \\
U3 & 6,55 & 5,13 & 6,70 \\
U4 & 6,55 & 5,25 & 6,78 \\
U5 & 6,58 & 5,25 & 6,68 \\
U6 & 6,58 & 5,03 & 6,75 \\
U7 & 6,53 & 5,15 & 6,73 \\
U8 & 6,53 & 5,15 & 6,73 \\
P & $<0,0001$ & $<0,0001$ & $<0,0001$ \\
SE & 0,004 & 0,004 & 0,004 \\
Rata-rata & $6,55^{\text {b }}$ & $5,24^{\text {c }}$ & $6,72^{\text {a }}$ \\
\hline
\end{tabular}

Keterangan: Superskrip berbeda pada baris yang sama menunjukan terdapat perbedaan yang nyata $(\mathrm{P}<0,01)$

Berdasarkan Tabel 1. menunjukkan bahwa Ampel (dataran tinggi) memiliki nilai $\mathrm{pH}$ lebih tinggi $(\mathrm{P}<0,05)$ dibandingkan dengan Demak (dataran rendah) dan Gunungpati (dataran sedang). Nilai $\mathrm{pH}$ berpengaruh terhadap kualitas daging ayam broiler. Hal ini disebabkan nilai $\mathrm{pH}$ mempengaruhi nilai keempukan, warna dan WHC daging ayam (Toplu et al., 2014). Nilai pH daging ayam yang dipelihara pada dataran rendah dan tinggi tergolong tinggi dan pada dataran sedang tergolong rendah. Hal ini sesuai dengan pendapat Song dan King (2015) bahwa nilai $\mathrm{pH}<5,7$ tergolong pale, soft, exudates (PSE), nilai $\mathrm{pH}$ 5,76,1 tergolong normal dan nilai $\mathrm{pH}>6,1$ tergolong tinggi. Nilai $\mathrm{pH}$ pada dataran rendah dan sedang yang memiliki nilai $\mathrm{pH}$ rendah, akibat nilai kelembaban dan heat index (HI) dataran rendah dan sedang yang lebih tinggi dibandingkan dengan dataran tinggi (Ampel). Hal ini menyebabkan ayam broiler mengalami stres. 
Stres mempercepat penguraian glikogen otot secara anaerob yang menyebabkan asam laktat menjadi tinggi. Tingginya asam laktat dapat mengakibatkan penurunan $\mathrm{pH}$ secara cepat, sehingga $\mathrm{pH}$ akhir menjadi rendah. Penurunan $\mathrm{pH}$ yang cepat ditentukan oleh laju glikolisis dan cadangan glikogen otot. Zhang et al. (2012) menyatakan bahwa ayam yang mengalami stres menunjukan $\mathrm{pH}$ akhir yang rendah.

\section{WHC Daging Ayam Broiler}

Ketinggian dataran tempat closed house berpengaruh nyata $(\mathrm{P}<0,05)$ terhadap water holding capacity (WHC) daging ayam broiler. Rata-rata nilai WHC daging ayam broiler berkisar antara 38,18-43,34\% (Tabel 2.).

Tabel 2. Hasil perbedaan ketinggian dataran terhadap WHC daging ayam broiler

\begin{tabular}{cccc}
\hline Ulangan & T1 & T2 & T3 \\
\hline U1 & 42,50 & 42,50 & 41,75 \\
U2 & 33,50 & 42,25 & 40,00 \\
U3 & 36,50 & 45,25 & 42,75 \\
U4 & 39,00 & 41,75 & 42,50 \\
U5 & - & 44,00 & 43,50 \\
U6 & 32,25 & 43,25 & 49,50 \\
U7 & 42,50 & 45,50 & 43,50 \\
U8 & 41,00 & 39,50 & 45,75 \\
P & 0,0054 & 0.0054 & 0,0054 \\
SE & 1,17 & 1,09 & 1,09 \\
Rata-rata & $38,18^{\mathrm{b}}$ & $43,00^{\mathrm{a}}$ & $43,66^{\mathrm{a}}$ \\
\hline
\end{tabular}

Keterangan: Superskrip berbeda pada baris yang sama menunjukan terdapat perbedaan yang nyata $(\mathrm{P}<0,05)$

Nilai WHC daging ayam broiler yang dipelihara di dataran tinggi (Ampel) dan sedang (Gunungpati) nyata $(\mathrm{P}<0,05)$ lebih tinggi dibandingkan dengan dataran rendah (Demak). Nilai WHC sangat mempengaruhi kualitas daging ayam broiler. Hal ini karena nilai WHC menggambarkan kerusakan protein pada daging ayam broiler. Nilai WHC daging ayam broiler yang tinggi $(\mathrm{P}>0,05)$ ditunjukan pada dataran sedang dan tinggi. Semakin tinggi nilai WHC, maka semakin baik daging dalam mengikat air sehingga kandungan nutrisi daging tidak banyak terbuang. Nilai WHC daging ayam broiler yang rendah $(\mathrm{P}<0,05)$ ditunjukan pada dataran rendah. Hal ini terkait dengan stress panas yang mengakibatkan denaturasi protein. Hal ini sesuai dengan pendapat Rini et al. (2019) bahwa ayam broiler yang dipelihara pada suhu yang tinggi $\left(35^{\circ} \mathrm{C}-36^{\circ} \mathrm{C}\right)$ mengalami stres panas yang menyebabkan denaturasi protein pada daging.

Denaturasi merupakan suatu proses perubahan konformasi struktur protein. Denaturasi protein dapat mengurangi kemampuan otot dalam daging untuk mengikat air, sehingga kandungan air dan nutrien dalam daging terbuang. Hal ini sesuai dengan pendapat Zhu et al. (2011) bahwa stres akibat suhu tinggi pada ternak menyebabkan denaturasi protein sarkoplasma yang berpengaruh terhadap interaksi antara permukaan protein dan fase air di sekitarnya, sehingga kapasitas penahan air berkurang.

Faktor yang mempengaruhi nilai WHC daging ayam yaitu: nilai $\mathrm{pH}$, suhu, kelembapan, lokasi otot, bangsa, pakan, pelayuan karkas dan tipe daging. Hasil penelitian menunjukan bahwa semakin tinggi nilai $\mathrm{pH}$ daging, maka semakin tinggi pula nilai $\mathrm{WHC}$ daging ayam. Nilai $\mathrm{pH}$ akhir yang tinggi menyebabkan protein dalam mengikat air menjadi tinggi dan daging menjadi kering. Hal ini sesuai dengan pendapat Dadgar (2010) bahwa nilai $\mathrm{pH}$ berbanding lurus dengan WHC.

\section{Susut Masak Daging Ayam Broiler}

Ketinggian dataran tempat closed house berpengaruh nyata $(\mathrm{P}<0,05)$ terhadap susut masak daging ayam broiler. Nilai rata-rata susut masak daging ayam broiler berkisar antara 31,94$34,13 \%$ (Tabel 3).

Tabel 3. Hasil perbedaan ketinggian dataran terhadap susut masak daging ayam broiler

\begin{tabular}{cccc}
\hline Ulangan & T1 & T2 & T3 \\
\hline U1 & 35,06 & 33,54 & 33,48 \\
U2 & 34,57 & 33,81 & 32,11 \\
U3 & 34,90 & 32,30 & 32,80 \\
U4 & 35,72 & 33,23 & 31,69 \\
U5 & 34,23 & 34,29 & 29,44 \\
U6 & 32,82 & 31,52 & 32,67 \\
U7 & 32,94 & 30,90 & 32,53 \\
U8 & 32,84 & 32,51 & 30,83 \\
P & 0,022 & 0,022 & 0,022 \\
SE & 0,34 & 0,34 & 0,34 \\
Rata-rata & $34,13^{\text {a }}$ & $32,76^{\text {a }}$ & $31,94^{\text {b }}$ \\
\hline
\end{tabular}

Keterangan: Superskrip berbeda pada baris yang sama menunjukan terdapat perbedaan yang nyata $(\mathrm{P}<0,05)$

Nilai rata-rata susut masak daging ayam broiler paling rendah $(\mathrm{P}<0,05)$ terjadi pada pemeliharaan di dataran tinggi. Susut masak 
daging ayam broiler pada dataran sedang dan tinggi tidak berbeda nyata $(\mathrm{P}>0,05)$. Susut masak menentukan nilai kualitas daging ayam. Semakin rendah nilai susut masak, maka semakin baik kualitas daging ayam. Nilai susut masak yang rendah menunjukan bahwa daging tidak banyak kehilangan cairan dan nutrisi selama proses pemasakan. Hal ini sesuai dengan pendapat Prayitno et al. (2010) bahwa daging yang berkualitas bagus memiliki susut masak yang rendah, karena kehilangan nutrien dan cairan sedikit saat pemasakan.

Faktor yang mempengaruhi nilai susut masak adalah WHC dan $\mathrm{pH}$ daging. Daging dengan nilai $\mathrm{pH}$ tinggi memiliki susut masak yang rendah. Nilai susut masak rendah memiliki nilai $\mathrm{pH}$ dan $\mathrm{WHC}$ daging ayam tinggi. Nilai $\mathrm{pH}$ dan WHC daging ayam yang tinggi memiliki kandungan protein yang tinggi. Kandungan protein dalam daging menyebabkan kemampuan dalam mengikat air menjadi tinggi. Hal ini sesuai dengan pendapat Hartati (2012) menyatakan bahwa susut masak yang tinggi mengakibatkan melemahnya ikatan-ikatan protein, sehingga kemampuan daya mengikat air melemah.

\section{Drip Loss Daging Ayam Broiler}

Ketinggian dataran tempat closed house berpengaruh nyata $(\mathrm{P}<0,05)$ terhadap drip loss daging ayam broiler yaitu Nilai rata-rata drip loss daging ayam broiler berkisar 5,08 - 9,12 (Tabel 4).

Tabel 4. Hasil perbedaan ketinggian dataran terhadap susut masak daging ayam broiler

\begin{tabular}{cccc}
\hline Ulangan & T1 & T2 & T3 \\
\hline U1 & 9,30 & 3,68 & 6,74 \\
U2 & 7,28 & 7,68 & 4,36 \\
U3 & 9,40 & 6,58 & 10,32 \\
U4 & 10,33 & 5,16 & 8,45 \\
U5 & 7,03 & 3,86 & 4,85 \\
U6 & 9,44 & 4,71 & 4,66 \\
U7 & 9,95 & 4,41 & 4,97 \\
U8 & 10,25 & 4,60 & 5,48 \\
P & 0,0003 & 0,0003 & 0,0003 \\
SE & 0,04 & 0,04 & 0,04 \\
Rata- & $9,12^{\mathrm{a}}$ & $5,08^{\mathrm{b}}$ & $6,23^{\mathrm{b}}$ \\
rata & & \\
\hline Kata
\end{tabular}

Keterangan: Superskrip berbeda pada baris yang sama menunjukan terdapat perbedaan yang nyata $(\mathrm{P}<0,05)$
Nilai rata-rata drip loss paling tinggi $(\mathrm{P}<0,05)$ ditunjukan pada pemeliharaan ayam broiler di daerah dataran rendah dengan nilai $9,12 \%$ (Tabel 4.). Nilai drip loss yang tinggi menunjukan banyaknya air dan nutrien yang keluar dari daging dan terjadi denaturasi protein. Hal ini sesuai dengan pendapat Kato et al. (2013) bahwa standar nilai drip loss untuk daging ayam segar tidak boleh melebihi 6\%. Pemeliharaan ayam broiler di daerah dataran rendah terjadi stres yang mengakibatkan ternak mengalami stres sehingga mempercepat denaturasi protein dan rigormortis. Daging yang mengalami denaturasi protein memiliki kemampuan dalam mengikat air yang rendah. Nkukwana et al. (2015) menyatakan bahwa daging yang mengalami denaturasi protein mengakibatkan fungsionalitasnya hilang sehingga kemampuan dalam mengikat air rendah. Stres mengakibatkan hilangnya integritas membran akibat dari menurunnya jumlah hematrokit dan meningkatnya kreatis kinase. Peningkatan keratin kinase menyebabkan nilai drip loss meningkat pada daging ayam broiler.

Drip loss memiliki hubungan dengan $\mathrm{pH}$ pada daging. Nilai drip loss yang rendah mengakibatkan nilai WHC yang tinggi. Hal ini ditunjukan oleh $\mathrm{T} 3$ yang memiliki nilai drip loss rendah dan nilai WHC tinggi. Hal ini sesuai dengan pendapat Brossi et al. (2012) bahwa nilai drip loss meningkat maka nilai WHC menurun. Nilai drip loss rendah mengakibatkan nilai $\mathrm{pH}$ tinggi yang disebabkan oleh stres jangka panjang akibat dari amonia yang tinggi pada T3. Stres pada ternak terjadi penguraian glikogen pada otot dalam proses glikolisis anaerob dan menghasilkan asam laktat yang sedikit pada daging ayam. Glikogen yang jumlahnya sedikit pada daging menyebabkan $\mathrm{pH}$ akhir tinggi dan daging lebih tinggidrip loss. Hal ini sesuai dengan pendapat $\mathrm{Lu}$ et al. (2017) bahwa stres panas mengakibatkan daging ayam broiler lebih tinggi drip loss.

\section{Warna Dada dan Paha Daging Ayam Broiler \\ Ketinggian dataran tempat closed house berpengaruh nyata $(\mathrm{P}<0,05)$ terhadap warna dada dan tingkat kecerahan paha daging ayam broiler. Sedangkan parameter lainnya tidak menunjukan pengaruh yang nyata $(\mathrm{P}>0,05)$.}


Tabel 5. Hasil perbedaan ketinggian dataran terhadap warna daging ayam broiler

\begin{tabular}{rccccc}
\hline Ulangan & $\mathrm{T} 1$ & $\mathrm{~T} 2$ & $\mathrm{~T} 3$ & $\mathrm{P}$ & $\mathrm{SE}$ \\
\hline Dada (L) & $53,84^{\mathrm{a}}$ & $54,62^{\mathrm{a}}$ & $49,37^{\mathrm{b}}$ & 0,0001 & 0,006 \\
(a) & $2,32^{\mathrm{b}}$ & $2,06^{\mathrm{b}}$ & $4,12^{\mathrm{a}}$ & 0,0065 & 0,061 \\
(b) & $7,30^{\mathrm{a}}$ & $7,71^{\mathrm{a}}$ & $6,34^{\mathrm{b}}$ & 0,013 & 0,019 \\
Paha (L) & $50,46^{\mathrm{b}}$ & $56,22^{\mathrm{a}}$ & $49,40^{\mathrm{b}}$ & 0,0081 & 0,008 \\
(a) & 5,77 & 5,74 & 7,30 & 0,20 & 0,043 \\
(b) & 6,56 & 6,69 & 6,22 & 0,58 & 0,024
\end{tabular}

Keterangan: Superskrip berbeda pada baris yang sama menunjukan terdapat perbedaan yang nyata $(\mathrm{P}<0,05)$

Nilai kecerahan daging dada dan paha di dataran sedang tergolong tinggi. Nilai kecerahan yang tinggi disebabkan oleh tingginya asam laktat sehingga terjadi penurunan $\mathrm{pH}$ yang sangat cepat dan menghasilkan $\mathrm{pH}$ yang rendah. Kinani et al. (2017) menyatakan bahwa penurunan $\mathrm{pH}$ yang cepat menyebabkan tingkat kecerahan daging ayam broiler meningkat. Nilai kecerahan yang tinggi daging menyebabkan daging menjadi pucat (PSE), sehingga tingkat kemerahan daging ayam rendah. Downing et al. (2017) menyatakan daging ayam dengan nilai kecerahan tinggi ( $>53)$ dikategorikan daging PSE. Nilai $\mathrm{pH}$ daging ayam broiler yang dipelihara di dataran tinggi sebesar 6,72 mengakibatkan warna daging lebih gelap. Nkukwana et al. (2015) menyatakan bahwa $\mathrm{pH}$ daging PSE yaitu $<5,7 ; \mathrm{pH}$ daging normal yaitu $5,7-6,1$ dan $\mathrm{pH}$ daging DFD yaitu $>6,1$.

Nilai kemerahan daging dada ayam broiler yang dipelihara di dataran tinggi nyata $(\mathrm{P}<0,05)$ lebih tinggi dibandingkan dengan dataran lainnya, sedangkan daging paha memiliki nilai warna kemerahan tidak berbeda nyata $(\mathrm{P}>0,05)$. Warna kemerahan (a) berhubungan erat dengan warna kecerahan daging (L). Semakin rendah tingkat kecerahan maka semakin tinggi nilai kemerahan daging. Hal ini sesuai dengan pendapat Dadgar et al. (2010) bahwa semakin rendah tingkat kemerahan daging, semakin tinggi tingkat kecerahan daging ayam broiler. Faktor yang mempengaruhi tingkat kemerahan daging yaitu $\mathrm{pH}$. Nilai kemerahan daging yang rendah disebabkan tingginya asam laktat sehingga menyebabkan penurunan $\mathrm{pH}$. Faktor yang mempegaruhi warna merah pada daging yaitu pigmen myoglobin dan hemoglobin. Menurut Tang et al. (2013) bahwa nilai $\mathrm{pH}$ yang rendah menyebabkan tingkat kemerahan daging rendah yang berkontribusi oleh reaksi redoks yang tidak biasa dari hemoglobin dan mioglobin.

Nilai kekuningan daging dada ayam broiler yang dipelihara pada dataran rendah dan sedang nyata $(\mathrm{P}<0,05)$ lebih tinggi dibandingkan dengan dataran tinggi, sedangkan nilai warna kekuningan daging paha tidak berbeda nyata $(\mathrm{P}>0,05)$. Nilai kekuningan yang tinggi ini disebabkan oleh kerusakan oksidatif yang menyebabkan myoglobin pada daging ayam teroksiasi menjadi oksimyoglobin sehingga warnanya berubah menjadi merah kekuningan. Peningkatan warna kekuningan terjadi karena kerusakan oksidatif pada daging ayam broiler. Nilai warna kekuningan diukur berdasarkan nilai kromatik. Nilai kromatik kekuningan 0 sampai 70 menunjukan warna kuning dan -70 sampai 0 menunjukan warna biru.

\section{KESIMPULAN}

Ketinggian dataran tempat closed house berpengaruh nyata terhadap nilai $\mathrm{pH}, \mathrm{WHC}$, susut masak, drip loss, dan warna dada (L,a,b) dan warna kecerahan (L) daging paha akan tetapi tidak mempengaruhi nilai kemerahan dan kekuningan daging paha ayam broiler. Semakin tinggi ketinggian dataran tempat closed house semakin bagus kualitas fisik daging ayam broiler yang dihasilkan. Ayam broiler sebaiknya dipelihara pada closed house pada dataran tinggi agar dapat menghasilkan kualitas fisik daging ayam broiler yang bagus.

\section{DAFTAR PUSTAKA}

Brossi, C., N. Montes-Villanueva, J. D. RiosMera, E. F. Delgado, J. M. Menten, C. J. Contreras-Castillo. 2018. Acute heat stress detrimental effects transpose high mortality rate and affecting broiler breast meat quality. Journal Scientia Agropecuaria 9 (3): 305-311.

Dadgar, S., E. S. Lee, T. L. V. Leer, N. Burlinguette, H. L. Classen, T. G. Crowe dan P. J. Shand. 2010. Effect of microclimate temperature during transportation of broiler chickens on quality of the pectoralis major muscle. Poult. Sci. 89 :1033-1041. 
Downing, J. A., M. J. Kerr dan D. L. Hopkins. 2017. The effects of pre-transport supplementation with electrolytes and betaine on performance, carcass yield and meat quality of broilers in summer and winter. J. Livestock Sci. 205: 16-23.

Hartati, S. 2012. Populasi Mikroba dan Sifat Fisik Daging Sapi Beku Selama Penyimpanan. Skripsi. Fakultas agroindustri. Universitas Mercu Buana. Yogyakarta.

Kanani, P.B., M. Daneshyar, J. Aliakbarlu dan F. Hamian. 2017. Effect of dietary turmeric and cinnamon powders on meat quality and lipid peroxidation of broiler chicken under heat stress condition. J. Vet. Res. Forum 8 (2): 163169 .

Kato, T., C.F. Barbosa, E.I. Ida, A.L. Soares, M. Shimokomaki dan M. R. Pedrao. 2013. Broiler chicken PSE (pale, soft, exudative) meat and water release during chicken carcass thawing and Brazilian Legislation. Brazilian. Arch. Biol. Technol. 56 (6): 9961001.

Lu, Z., X. He,B. Ma,L. Zhang,J. Li,Y. Jiang, G. Zhou dan F. Gao. 2017. Chronic heat stress impairs the quality of breast-muscle meat in broilers by affecting redox status and energy-substance metabolism. J. Agric. Food Chem. 65 (51): 11251-11258.

Nkukwana, T.T., V. Muchenje, P.J. Masika, E. Pieterse, L.C. Hoffman dan K. Dzama. 2015. Proximate composition and variation in colour, drip loss and $\mathrm{pH}$ of breast meat from broilers supplemented with Moringa oleifera leaf meal over time. Anim. Prod. Sci. 56: 1208-1216.

Prayitno A. H, E. Suryanto dan Zuprizal. 2010. Kualitas fisik dan sensoris daging ayam broiler yang diberi pakan dengan penambahan ampas virgin coconut oil (vco). Buletin Peternakan 34 (1):55-63.

Rini, S. R., Sugiharto dan L.D. Mahfudz. 2019. Pengaruh perbedaan suhu pemeliharaan terhadap kualitas fisik daging ayam broiler periode finisher. Jurnal Sains Peternakan Indonsesia. 14 (4) : 387 - 395.

Tang, S., J. Yu, M. Zhang dan E. Bao. 2013. Effects of different heat stress periods on various blood and meat quality parameters in young Arbor Acer broiler chickens. Can. J. Anim Sci.93 : 453-460.

Zhang, Z. Y., G. Q. Jia, J. J. Zuo, Y. Zhang, J. Lei, L. Ren dan D.Y. Feng. 2012. Effects of constant and cyclic heat stress on muscle metabolism and meat quality of broiler breast fillet and thigh meat. Poult. Sci. 91 :2931-2937.

Zhu, X., M. Ruusunen, M. Gusella, M. YläAjos, X. Xu, G. Zhou and E. Puolanne. 2013. High early post-mortem temperature induces activation of AMP-activated protein kinase and development of pale, soft and exudative characteristics in turkey muscles. Meat Sci. 93: 600-606. 